\title{
MODEL LAYANAN KLASIKAL TEKNIK HOME ROOM BERBASIS ONLINE MENGURANGI FOMO MENGGUNAKAN MEDIA SOSIAL
}

\author{
Desy Mustika1, Akhmad Rizkhi Ridhani², ${ }^{1}$ Farial $^{3}$ \\ ${ }^{1}$ Mahasiswa Prodi Bimbingan dan Konseling, FKIP, UNISKA MAB, Indonesia \\ ${ }^{2}$ Dosen Prodi Bimbingan dan Konseling, FKIP, UNISKA MAB, Indonesia \\ ${ }^{3}$ Dosen Prodi Bimbingan dan Konseling, FKIP, UNISKA MAB, Indonesia \\ E-mail:desymustika94@gmail.com, rizkhi ridhani@gmail.com, varialuniska@gmail.com
}

\begin{abstract}
ABSTRAK
Penelitian melahirkan model pengembangan layanan klasikal teknik homeroom berbasis online untuk mengurangi rasa FoMo dalam menggunakan media sosial pada masyarakat Kalselteng. Dampak dari pandemi mengharuskan tetap berada dirumah sedangkan kebanyakan masyarakat menghabiskan waktu dirumah dengan bermain smartphone dan mengakses media sosial. Penggunaan media sosial yang kurang tepat memicu timbulnya rasa FoMO dalam menggunakan media sosial. Penelitian ini merupakan penelitian R\&D dengan prosedur pengembangan yang sudah dimodifikasi yaitu studi pendahuluan, pengembangan model, uji validasi model, dan revisi model. Untuk mengetahui kondisi masyarakat yang mengalami FoMO berdasarkan hasil wawancara dan observasi. Bentuk model yang dikembangkan telah melalui uji validasi ahli dan praktisi.
\end{abstract}

Kata Kunci: Fomo, Layanan Klasikal, Teknik Home Room

\begin{abstract}
The research gave birth to a classic service development model for online-based homeroom techniques to reduce the feeling of FoMo in using social media in the people of South Kalimantan. The impact of the pandemic requires staying at home while most people spend time at home playing smartphones and accessing social media. Inappropriate use of social media triggers a sense of FoMO in using social media. This research is an R\&D research with modified development procedures, namely preliminary studies, model development, model validation tests, and model revisions. This is to determine the condition of the community experiencing FoMO based on the results of interviews and observations. The form of the model developed has gone through expert and practitioner validation tests.
\end{abstract}

Keywords: Fomo, Classical Services, Homeroom Engineering 


\section{PENDAHULUAN}

Teknologi informasi dan komunikasi mengalami perkembangan sangat pesat dalam beberapa waktu terakhir. Pesatnya perkembangan teknologi menjadikan internet bukan lagi hal tabu untuk dikenal oleh masyarakat. Kemudahan dalam mengakeses internet dapat dilakukan dimana saja dan kapan saja, dimana penggunanya hanya membutuhkan smartphone yang terhubung dengan koneksi jaringan. Kehadiran smartphone juga menyediakan beberapa fitur didalamnya agar kita dapat menjalin komunikasi diantaranya melalui email, instagram, facebook, line dan berbagai macam jenis aplikasi untuk media sosial lainya. Fathadika (2018) menyebutkan media sosial merupakan alat komunikasi yang banyak digunakan saat ini dan kalangan remaja menjadi pengguna terbesar di Indonesia. Salah satu alasan remaja menjadi pengguna terbesar media sosial adalah mereka lahir dan tumbuh di era informasi digital yang sedang berkembang pesat.

Selaras dengan APJII bahwa pengguna internet terbanyak adalah pelajar dan mahasiswa, mereka akan berusaha untuk selalu terhubung dengan media sosial jika tidak mereka akan merasa tersingkir dari teman-teman ketika tidak menggunakan media sosial. Agar tidak tersingkir dari teman-temannya mereka harus up to date dengan perkembangan baik dari segi berita, fashion, kuliner dan tempat-tempat yang sedang booming pada saat itu dimedia sosial. Dengan demikian masyarakat tidak dapat terlepas dari smartphone sehingga memicu munculnya sebuah kecemasan jika tertinggal dengan informasi terkini yang dikenal dengan istilah FoMO (Fear of Missing Out).
Istilah FoMO pertama kali digunakan pada tahun 2013 di dalam sebuah penelitian ilmiah yang dilakukan oleh Przybylski, Murayama, DeHaan, dan Gladwell (dalam Anggraini, 2014). Przybylski mendefinisikan FoMO sebagai kekhawatiran yang dialami individu ketika orang lain memiliki pengalaman yang mengesankan disaat ketidakahadiran dirinya. Jika gangguan FoMO terus berlanjut maka akan banyak orang yang lebih mementingkan dunia maya kebanding dunia nyata, dimana individu akan terobsesi dengan segala bentuk aktivitas orang lain, serta ada rasa tidak puas dengan kehidupan yang dimilikinya. Sehingga harus ada solusi yang diambil agar bisa mengurangi rasa FoMO yang ditimbulkan dari media sosial. Salah satu pilihan layanan yang dapat digunakan untuk mengurangi rasa FoMO adalah dengan pemberian layanan klasikal. Dengan kemajuan teknologi maka pemberian layanan klasikal dilakukan secara online dengan menggunakan teknik homeroom.

Menurut Romlah (dalam Hidayat, 2018) teknik homeroom adalah teknik yang menciptakan suasana kekeluargaan yang digunakan untuk mengadakan pertemuan dengan sekelompok orang diluar jam pelajaran dalam suasana kekeluargaan, dan dipimpin oleh guru atau konselor. Adapun tujuan dari pelaksanaan bimbingan klasikal teknik homeroom menurut Nursalim (dalam Hidayat, 2018) adalah untuk membicarakan beberapa hal yang dianggap perlu terutama hal-hal atau masalah yang berhubungan dengan pelajaran, kegiatan sosial, masalah tata tertib dan moral, cara berpakaian, atau masalah-masalah lain di luar sekolah. Berdasarkan pemaparan para ahli teknik homeroom merupakan teknik yang dilakukan oleh konselor kepada sekelompok individu 
dengan menciptakan suasana kekeluargaan dan bertujuan untuk membicarakan hal-hal atau masalah yang dianggap perlu untuk diselesaikan. Dalam pelaksanaan teknik homeroom, berlangsung secara bebas dan santai sehinga memungkinkan anggotanya untuk dapat berpendapat dan mengekspresikan perasaan.

Berdasarkan observasi dan wawancara dengan masyarakat Kalselteng mengenai penggunaan media sosial yang kurang tepat sehingga menimbulkan rasa FoMO menjadi alasan untuk melaksanakan penelitian dengan mengembangkan model dari layanan klasikal teknik homeroom berbasis online untuk mengurangi rasa FoMo dalam menggunakan media sosial pada masyarakat Kalselteng.

\section{METODE}

Penelitian ini merupakan R\&D (research and development). Menurut Borg and Gall (dalam Ridhani 2020) prosedur dalam penelitian pengembangan yang telah dimodifikasi meliputi : (1) studi pendahuluan, (2) pengembangan hipotetik, (3) validasi ahli, (4) revisi.

Pada tahap studi pendahuluan peneliti mencoba untuk mencari fenomena atau permasalah yang muncul di lapangan. Kondisi nyata yang terjadi dilapangan di tengah pandemi dari covid-19 ini menjadi dasar pemikiran peneliti untuk mengembangkan layanan klasikal. Studi pendahuluan terhadap sampel dengan menganalisis atau mengobservasi keadaan sampel. Selain itu juga melakukan wawancara dengan pihak terkait yaitu, masyarakat pengguna aktif media sosial di kalimantan tengah untuk memperoleh informasi yang dibutuhkan. Peneliti juga mencari informasi berdasakan literatur dari penelitian terdahulu yang relevan dengan tema yang akan diteliti.

Pada tahapan pengembangan langkah yang dilakukan adalah sebagai berikut : (1) Merancang model hipotetik layanan klasikal yang dikembangkan berdasarkan kajian hipotetik, kondisi obyektif pada masyarakat di Kalimantan, kajian hasil penelitian terdahulu, serta ketentuan formal pelaksanaan layanan klasikal pada masyarakat di Kalimantan, (2) Melakukan konsultasi dengan pembimbing agar model yang nantinya akan dihasilkan layak secara teoritik dan efektif untuk digunakan untuk mengurangi rasa FoMO dalam menggunakan media sosial pada masyarakat di Kalimantan.

Pada tahapan validasi ahli peneliti memvalidasi model yang dikembangkan kepada para ahli ilmu bimbingan dan konseling untuk mendapatkan, tanggapan, masukan, serta kritik dan saran sebagai bahan rujukan untuk revisi model yang sedang dikembangkan. Adapun kriteria para ahli untuk memvalidasi produk yang dikembangkan peneliti adalah : (1) dua orang dosen yang ahli dalam bimbingan dan konseling (S2 bimbingan dan konseling), dan tiga orang guru bimbingan da konseling dari tiga sekolah berbeda, dua dari sekolah di Muara Teweh dan satu orang guru dari sekolah di Banjarmasin (S1 Bimbingan dan Konseling). Adapun teknik dan instrumen pengumpul data dalam pengembangan model ini yaitu wawancara tidak terstruktur, observasi tidak terstruktur, dan lembar validasi ahli.

Pada tahap revisi peneliti telah mendapatkan masukan dan saran dari validator, maka peneliti melakukan pengkajian ulang terhadap produk yang telah divalidasi oleh validator, serta melakukan perbaikan sesuai dengan 
masukan yang diberikan validator, sehingga tersusunnya model hipotetik layanan klasikal teknik homeroom berbasis online untuk mengurangi rasa FoMO dalam menggunakan media sosial pada masyarakat di Kalimantan. Dalam revisi model layanan klasikal peneliti terus bekerjasama dengan pembimbing agar memperoleh masukan lebih jauh agar model layanan klasikal teknik homeroom berbasis online yang dihasilkan memiliki tingkat kelayakan yang tinggi untuk diterapkan dalam mengurangi rasa FoMO dalam menggunakan media sosial pada masyarakat di Kalimantan.

Pada penelitian ini peneliti
menggunakan teknik analisa data
menganalisis nontes yang diperoleh melalui kegiatan observasi, dokumentasi, dan wawancara. Menurut Ridhani (2020) penelitian deskriptif biasanya mempunyai dua tujuan, yang pertama adalah untuk mengetahui perkembangan fisik tertentu atau frekuensi tersedianya suatu aspek fenomena sosial tertentu. Yang kedua adalah untuk mendeskripsikan secara terperinci fenomena sosial tertentu seperti, interaksi, sosial, sostem kekerabatan dan lain-lain.

Menurut Miles dan Huberman dalam Ridhani (2020) teknik analisa data yang digunakan untuk menganalisa masalah yang sudah ditentukan terlebih dahulu terdiri dari empat komponen analisis yaitu : (1) pengumpulan data, data yang dikumpulkan dari pengamatan atau observasi, wawancara dan dokumentasi dicatat dalam catatan lapangan, yang terdiri dua bagian, pertama catatan kasus yang merupakan catatan tentang fenomena yang diamati, didengar, dilihar dan dialami sendiri oleh peneliti secara apa adanya. Kedua catatan reflektif yang merupakan catatan berisi kesan, komentar, tafsiran peneliti tentang fenomena yang baru saja dijumpai/ dalam catatan refeleksi peneliti mulai melakukan penarikan kesimpulan awal yang bersifat sementara pada data secara sendiri-sendiri. Disamping itu dalam catatan lapangan dibuat renca untuk kegiatan pengumpulan data pada taha berikutnya. (2) reduksi data, Data yang dicatat dalam catatan lapangan yang jumlahnya banyak akan mempersulit penarikan kesimpulan, maka perlu disingkat, dirangkum dan dipilih data yang penting serta berkaitan langsung dengan pokok persoalan kegiatan ini disebut reduksi data. Reduksi data dilakukan dengan hati-hati dan diulang terus untuk menghindari kemungkinan terjadi kekeliruan dalam mereduksi, karena dapat saja data yang ternyata penting dan perlu, tetapi direduksi, dan data yang tidak penting justru tidak direduksi. (3) sajian data, Data telah direduksi, perlu disajikan dalam bentuk tulisan yang disusun secara sistematik, atau dibuat marik, grafik atau tabel, supaya mudah dilihat dan dipahmi hubungannya antara satu data dengan lainnya, sehingga memudahkan penarikan kesimpulan. (4) penarikan kesimpulan, Penarikan kesimpulan dilakukan selama penelitian berlangsung. Data yang diperoleh sejak awal peneliti sudah mulai ditafsirkan dan diambil kesimpulannya. Rasa FoMO data masih sedikit jumlahnya, kesimpulan yang ditarik masih belum jelas, makin banyak dapat yang didapat, maka kesimpulan akan semakin jelas.

\section{HASIL DAN PEMBAHASAN}

Berdasarkan rumusan masalah yang telah ditetapkan oleh peneliti dan tujuan dalam penelitian, desain penelitian ini menggunakan penelitian dan pengembangan 
(research and development). Adapun pengembangan yang dimaksud dalam penelitian ini adalah pengembangan model layanan klasikal teknik homeroom berbasis online untuk mengurangi rasa FoMO dalam menggunakan media sosial pada masyarakat Kalselteng. Penelitian ini juga telah melewati beberapa tahapan sesuai dengan tahapan yang telah ditentukan. Adapun tahapan yang telah ditentukan sebagai berikut :

Tahapan pendahuluan, dimana peneliti mencoba mencari fenomena atau permasalahan yang muncul dilampangan. Kondisi nyata yang terjadi dilapangan merupakan dasar dari pemikiran peneliti dalam mengembangan model ini. Peneliti melakukan wawancara tidak terstruktur pada klien serta peneliti telah melakukan observasi tidak terstruktur. Adapun kondisi faktual pada masyarakat Kalselteng yang mengalami FoMO dimana diawali dengan tidak terlepas dari handphone serta pengaksesan media sosial yang mudah merupakan awal dari munculnya rasa FoMO pada individu. Adapun kriteria FoMO dalam penelitian ini adalah ditandai dengan adanya rasa ingin tahu yang berlebihan tentang aktivitas atau informasi orang lain, eksistensi diri yang selalu ingin diakui oleh orang lain, cemas jika tertinggal dari kelompok atau teman-temannya, kurangnya memanfaatkan waktu dengan bersosialisasi dan menghabiskan waktu secara positif. Kemudian gejala yang ditimbulkan dari rasa FoMO sendiri yaitu, terlalu sering mengecek notifikasi pada akun sosial media, merasa cemas jika tertinggal akan hal-hal yang sedang booming pada saat itu, cemas jika lebih sedikit yang memberikan like atau melihat postingan yang telah diunggah pada media sosialnya. Serta dampaknya yaitu menimbulkan kurangnya bersosialisai dengan lingkungan sekitar dan menghabiskan waktu dengan bermain handphone.

Tahap pengembangan model yang digunakan, adapun langkah-langkah yang dilakukan peneliti dalam mengembangkan model yang digunakan adalah sebagai berikut : (1) merancang model layanan klasikal teknik homeroom berbasis online untuk mengurangi rasa FoMO dalam menggunakan media sosial pada masyarakat Kalselteng berdasarkan penelitian terdahulu. (2) mengkonsultasikan model yang dikembangkan dengan dosen pembimbing 1 dan dosen pembimbing 2 agar model yang dikembangkan layak serta dan digunakan dalam memberikan layanan klasikal.

Tahap kelayakan model, pada tahapan ini peneliti meminta bantuan kepada dosen pembimbing agar dapat mengarahkan peneliti untuk memvalidasi model yang telah dikembangkan. Pada tahap ini peneliti memvalidasi model yang dikembangakan memuat validasi akademisi dan validasi praktisi. Pada tahapan validasi peneliti mendapatkan masukan, tanggapan, serta kritik dan saran sebagai bahan rujukan untuk merevisi model yang sedang dikembangkan. Adapun kriteria validator dalam penelitian ini dituliskan dalam tabel $\mathbf{1}$.

\section{Kriteria Validator.}

Tahap revisi, pada tahapan ini peneliti telah menerima masukan dan saran dari validator yang sudah ditentukan peneliti dan dapat dilihat pada tabel 2. Masukan dan Saran Validator. Kemudian mendapatkan beberapa kekurangan pada model yang dikembangkan maka peneliti melakukan kajian ulang terhadap model yang dikembangkan. Berikut masukan dan saran dari validator akademisi dan validator praktisi yang telah ditetapkan peneliti dapat 
dilihat pada tabel 3. Hasil Perbaikan Model.

Tabel 1. Kriteria Validator

\begin{tabular}{|c|c|}
\hline Validator & Kriteria \\
\hline Akademisi & $\begin{array}{l}\text { 1. Terdapat } 2 \text { orang akademisi bidang } \\
\text { bimbingan dan konseling. } \\
\text { 2. Berkualifikasi pendidikan minimal S2 } \\
\text { linear bidang bimbingan dan konseling. } \\
\text { 3. Memiliki keahlian dalam pengembangan } \\
\text { program layanan bimbingan dan } \\
\text { konseling. }\end{array}$ \\
\hline Praktisi & $\begin{array}{l}\text { 1. Terdapat } 3 \text { orang praktisi bidang } \\
\text { bimbingan dan konseling. } \\
\text { 2. Berkualifikasi pendidikan minimal } \mathrm{S} 1 \\
\text { bidang pendidikan bimbingan dan } \\
\text { konseling. } \\
\text { 3. Bekerja pada lembaga pendidikan yang } \\
\text { menyediakan bimbingan dan konseling. } \\
\text { 4. Berpengalaman menjadi wali kelas di } \\
\text { lembaga pendidikan. }\end{array}$ \\
\hline
\end{tabular}

Tabel 2. Masukan dan Saran Validator

\begin{tabular}{|c|c|c|}
\hline No & Validator & Masukan dan Saran \\
\hline \multicolumn{3}{|r|}{ Validator Akademisi } \\
\hline & Validator 1 & $\begin{array}{l}\text { Secara umum model ini sudah disusun secara komprehensif } \\
\text { walaupun memerlukan beberapa perbaikan guna } \\
\text { menyempurnakan. Jabarkan secara detail prosedur } \\
\text { pelaksanaan layanan dari sesi } 1-8 \text {. Tambahkan TAHAPAN } \\
\text { KHUSUS dan tahapan yang sudah ada ganti dengan } \\
\text { TAHAPAN UMUM materi pertemuan ke } 1,2,7 \text {, dan } 8 \text { masih } \\
\text { teoritik jangan terlalu berpatok dengan teori karna akan } \\
\text { menyebabkan kebingungan.. Mungkin kedepannya akan lebih } \\
\text { baik jika model ini memiliki platform aplikasi tersendiri karena } \\
\text { adanya keterbatasan dalam menggunakan aplikasi zoom dan } \\
\text { google meet. }\end{array}$ \\
\hline 2 & Validator 2 & Panduan yang dibuat sudah siap digunakan dengan sedikit \\
\hline
\end{tabular}


3 Validator 3

$4 \quad$ Validator 4

$5 \quad$ Validator 5 perbaikan sesuai saran seperti nemambahkan cover depan untuk panduan, melampirkan format evaluasi, dan RPL.

\section{Validator Praktisi}

Pada model layanan klasikal teknik homeroom berbasis online sebaiknya tidak hanya menggunakan satu aplikasi saja, bisa dibarengi dengan aplikasi lain yang memadai seperti whatsapp dan google meet.

Saran saya yang pertama agar dikaji ulang tentang subjek yang terlalu luas, yaitu masyarakat kalsel dan kalteng merupakan dua provinsi yang berbeda, alangkah lebih baik apabila sasaran pada sekolah atau warga kampus terlebih dahulu.

Tambahkan pengertian JoMO, indikator batasan mengenal JoMO pada panduan model R\&D 
Tabel 3. Hasil Perbaikan Model

\section{Tema Masukan}

\section{Model Sebelum Perbaikan}

\section{Model Sesudah \\ Diperbaiki}

Isi layanan klasikal teknik homeroom berbasis online
Bagian ini diisi dengan deskripsi ringkas layanan homeroom mengenai model teknik online. dan kelemahan model ini serta peran konselor dan klien.

Tahapan layanan klasikal teknik homeroom berbasis online

ada ganti menjadi tahap
Sudah diringkas, sudah tambahkan kelebihan dan kelemahan model ini, serta peran konselor dan siswa juga sudah ditambahkan pada model layanan klasikal teknik homeroom berbasis online.

Sudah ditambahka tahapan khusus dan sudah diganti tahapan yang telah ada dengan tahapan umum.

Pada pertemuan ke 1,2,7, dan 8 materi yang disampaikan telah di ganti agar tidak terjadi kebingungan pada klien.
Kesesuasian topik, materi Materi pada pertemuan 1,2,7, tujuan, dan teknik dalam dan 8 terlalu terpaku pada teori pelaksanaan layanan klasikal

teknik homeroom berbasis kebingungan. online. karna akan menyebabkan umum.

Berdasarkan masukan dan saran di atas yang telah diberikan validator kepada peneliti, kemudian peneliti telah merevisi atau memperbaiki pengembangan model sesuai dengan masukan dan saran yang diberikan validator.

Penelitian pengembangan model ini bertujuan untuk mengetahui bentuk pengembangan model layanan klasikal teknik homeroom berbasis online untuk mengurangi rasa FoMO dalam menggunakan media sosial pada masyarakat Kalselteng. Pengembangan dalam model ini dilakukan karna mengingat dari pandemi yang mengharuskan proses belajar mengajar secara daring. Selain proses belajar secara daring masyarakat juga diminta untuk tetap stay at home atau tetap dirumah. Mengahabiskan waktu dirumah dilakukan dengan bermain handphone, dengan kemudahan dan berbagai macam fitur yang disediakan handphone. Salah satu fitur yang disediakan handphone adalah media sosial, dengan media sosial individu dapat berinteraksi dengan siapapun, tidak terbatas jarak, dan kapan saja hanya dengan bantuan konseksi internet. Berdasarkan hasil dari observasi dan wawancara pada masyarakat Kalselteng dimana kebanyakan menghabiskan waktu dirumah dengan bermain sosial media sehingga menimbulkan ketertarikan bagi peneliti untuk melakukan 
penelitian mengenai pengembangan dalam memberikan layanan klasikal yang tujuannya untuk mengurangi rasa FoMO dalam menggunakan media sosial. Maka dari itu peneliti ingin mengembangkan model dalam memberikan layanan klasikal. Model yang dikembangkan adalah model layanan klasikal teknik homeroom berbasis online untuk mengurangi rasa FoMO dalam menggunakan media sosial.

Przyblyski, dkk (dalam Anggraini 2014) mendefinisikan Fear Of Missing Out adalah suatu ketakutan yang dialami seseorang saat kehilangan sesuatu yang berharga dan tidak dapat mengikuti apa yang dilakukan oleh orang lain di media sosial. Oleh karena itu, individu ingin selalu terhubung dengan media sosial. Selaras dengan pendapat JWTIntelegence (2012) rasa FoMO merupakan ketakutan pada individu yang apabila individu lainnya mengikuti suatu kejadian yang dianggap menyenangkan, namun individu tersebut tidak bisa mengikuti suatu kejadian tersebut. Rasa FoMO didefinisikan sebagai pemahaman yang kuas bahwa individu akan mendapatkan suatu kejadian meskipun individu tersebut tidak hadir di dalamnya Przyblyski dkk, (dalam Anggraini 2014). Rasa FoMO mencakup dengan emosi negatif yang mempengaruhi perilaku, dimana perilaku tersebut berhubungan dengan keterlibatan sosial yang membuat individu selalu terhubung dengan media sosial Hetz, (dalam Mudrikah 2019).

Berdasarkan hal ini dibutuhkan pemberian layanan dalam bimbingan dan konseling untuk mengurangi rasa FoMO yang dialami masyarakat dengan menggunakan teknik-teknik tertentu yang dapat menciptakan suasana kekeluargaan dalam pelaksanaannya. Selaras dengan
Romlah (dalam Nugroho 2014) teknik homeroom merupakan teknik yang mengadakan pertemuan diluar jam pelajaran dengan sekelompok siswa dalam suasana kekeluargaan dan dipimpin oleh guru atau konselor. Dengan suasana yang menyenangkan dan akrab diharapkan siswa dapat mengungkapkan masalah yang tidak dapat dibicarakan dalam kelas pada waktu jam pelajaran. Dengan dilaksanakannya kegiatan layanan klasikal menggunakan teknik homeroom diharapkan dapat membantu siswa untuk menurunkan rasa FoMO. Sehingga rasa FoMO yang dialami masyarakat dapat teratasi dan perkembangan individu menjadi lebih optimal dengan bijak dalam memilah informasi di media sosial.

\section{SIMPULAN}

Pengembangan dalam model ini dilakukan karna mengingat dari pandemi yang mengharuskan proses belajar mengajar secara daring. Selain proses belajar secara daring masyarakat juga diminta untuk tetap stay at home atau tetap dirumah. Mengahabiskan waktu dirumah dilakukan dengan bermain handphone, dengan kemudahan dan berbagai macam fitur yang disediakan handphone. Salah satu fitur yang disediakan handphone adalah media sosial, dengan media sosial individu dapat berinteraksi dengan siapapun, tidak terbatas jarak, dan kapan saja hanya dengan bantuan konseksi internet. Berdasarkan hasil dari observasi dan wawancara pada masyarakat Kalselteng dimana kebanyakan menghabiskan waktu dirumah dengan bermain sosial media sehingga menimbulkan ketertarikan bagi peneliti untuk melakukan penelitian mengenai pengembangan dalam memberikan layanan klasikal yang tujuannya 
untuk mengurangi rasa FoMO dalam menggunakan media sosial. Maka dari itu peneliti ingin mengembangkan model dalam memberikan layanan klasikal. Model yang dikembangkan adalah model layanan klasikal teknik homeroom berbasis online untuk mengurangi rasa FoMO dalam menggunakan media sosial.

Przyblyski, dkk (dalam Anggraini 2014) mendefinisikan Fear Of Missing Out adalah suatu ketakutan yang dialami seseorang saat kehilangan sesuatu yang berharga dan tidak dapat mengikuti apa yang dilakukan oleh orang lain di media sosial. Oleh karena itu, individu ingin selalu terhubung dengan media sosial. Selaras dengan pendapat JWTIntelegence (2012) rasa FoMO merupakan ketakutan pada individu yang apabila individu lainnya mengikuti suatu kejadian yang dianggap menyenangkan, namun individu tersebut tidak bisa mengikuti suatu kejadian tersebut. Rasa FoMO didefinisikan sebagai pemahaman yang kuas bahwa individu akan mendapatkan suatu kejadian meskipun individu tersebut tidak hadir di dalamnya Przyblyski dkk, (dalam Anggraini 2014). Rasa FoMO mencakup dengan emosi negatif yang mempengaruhi perilaku, dimana perilaku tersebut berhubungan dengan keterlibatan sosial yang membuat individu selalu terhubung dengan media sosial Hetz,(dalam Mudrikah 2019).

Berdasarkan hal ini dibutuhkan pemberian layanan dalam bimbingan dan konseling untuk mengurangi rasa FoMO yang dialami masyarakat dengan menggunakan teknik-teknik tertentu yang dapat menciptakan suasana kekeluargaan dalam pelaksanaannya. Selaras dengan Romlah (dalam Nugroho 2014) teknik homeroom merupakan teknik yang mengadakan pertemuan diluar jam pelajaran dengan sekelompok siswa dalam suasana kekeluargaan dan dipimpin oleh guru atau konselor. Dengan suasana yang menyenangkan dan akrab diharapkan siswa dapat mengungkapkan masalah yang tidak dapat dibicarakan dalam kelas pada waktu jam pelajaran. Dengan dilaksanakannya kegiatan layanan klasikal menggunakan teknik homeroom diharapkan dapat membantu siswa untuk menurunkan rasa FoMO. Sehingga rasa FoMO yang dialami masyarakat dapat teratasi dan perkembangan individu menjadi lebih optimal dengan bijak dalam memilah informasi di media sosial.

\section{DAFTAR PUSATAKA}

Anggraini, L. (2014). Fenomena FoMO (Fear Of Missing Out) Sebagai Salah Satu Bentuk Motivasi Konsumen Millenial.

Fathadika, S., \& Afriani. (2018). Social Media Engagement Sebagai Mediator Antara Fear of Missing out Dengan Kecanduan Media Sosial Pada Remaja. Jurnal Psikologi Sains dan Profesi. Vol 2, No 3.

Hidayat, F., Zamroni, E., Sucipto. (2018). Layanan Bimbingan Kelompok Teknik Homeroom Untuk Meningkatkan Sikap Anti Seks Bebas. Jurnal Prakarsa Paedagogia. Vol.1 No. 2

JWT Intellegence. (2012). Fear Of Missing Out (FoMO). New York: JWT Intellegence. 
Mudrikah,C. (2019). Hubungan Antara Sindrom FoMO (Fear Of Missing Out) Dengan Kecenderungan Nomophibia Pada Remaja.

Nugroho, W.D. (2014). Efektifitas Layanan Bimbingan Kelompok Teknik Homeroom Dalam Meningkatkan Motivasi Belajar Siswa Kelas VIII Di SMP Negeri 1 Rakit Kabupaten Banjarnegara.

Ridhani, A.R., Aminah, Fauzi.Z. (2020). Aplikasi Daftar Cek Masalah Bagi Anak Usia Dini Di Wilayah Lahan Rawa. Jurnal Bimbingan Konseling Islam \& Kemasyarakatan. 